\title{
PENAMBAHAN BUBUK EKSTRAK KUBIS MERAH (BRASSICA OLERACEAE VAR. CAPITATA F. RUBRA) SEBAGAI SUMBER ANTIOKSIDAN DAN PEWARNA ALAMI PADA CHEESECAKE
}

\author{
Addition of Red Cabbage Extract Powder \\ (Brassica oleraceae var. capitata f. rubra) as Antioxidant Source and \\ Natural Colors in Cheesecake
}

\author{
Rosalia Nidyasari Wuwur, Yuliana Reni Swasti*, Franciscus Sinung Pranata \\ Jurusan Biologi - Fakultas Teknobiologi - Universitas Atma Jaya Yogyakarta \\ Jl. Babarsari - Daerah Istimewa Yogyakarta 55281 \\ *Korespondensi Penulis, email: reni.swasti@uajy.ac.id
}

Disubmit : 25 Juni 2020

Direvisi : 3 Februari 2021

Diterima : 23 Desember 2021

\begin{abstract}
ABSTRAK
Antosianin merupakan pigmen warna pada tumbuhan yang memiliki aktivitas antioksidan. Antosianin dapat ditemukan pada tumbuhan yang berwarna biru atau merah seperti kubis merah. Upaya untuk meningkatkan antioksidan pada bahan pangan salah satunya dengan cara menambahkan bubuk ekstrak antosianin dari tanaman ke dalam bahan pangan sebagai pewarna alami. Produk makanan yang dapat diberi tambahan pewarna salah satunya adalah kue. Cheesecake yang diberi tambahan bubuk ekstrak kubis merah diharapkan dapat disukai karena memiliki penampilan yang menarik dan memiliki manfaat sebagai antioksidan. Tujuan dari penelitian ini adalah untuk mengetahui pengaruh penambahan bubuk ekstrak kubis merah terhadap kualitas kimia, fisik, mikrobiologi dan organoleptik cheesecake serta mengetahui konsentrasi terbaik penambahan bubuk ekstrak kubis merah. Rancangan percobaan yang digunakan pada penelitian ini adalah Rancangan Acak Lengkap (RAL) dengan variasi bubuk ekstrak kubis merah 0\% (kontrol), 5\% (A), 10\% (B), dan 15\% (C). Hasil penelitian ini menunjukkan bahwa cheesecake dengan variasi penambahan bubuk ekstrak kubis merah mempunyai kadar air 42,38-49,06\%, kadar abu 0,64-0,84\%, kadar protein 4,57-4,81\%, kadar lemak 27,17-31,85\%, kadar karbohidrat 13,98-24,90\%, total fenolik 0,76-1,16 mg GAE/g DW, aktivitas antioksidan 27,27-55,58\%, total asam tertitrasi (TAT) 0,01-0,02\%, dan uji mikrobiologi yang terdiri dari uji Salmonella dan angka lempeng total yang sudah memenuhi standar yang ditetapkan oleh USDA (United State Department of Agriculture) dan BSN (Badan Standardisasi Nasional). Hasil organoleptik menunjukkan bahwa cheesecake A $(5 \%)$ merupakan produk yang paling disukai oleh panelis
\end{abstract}

Kata kunci: Bubuk Ekstrak Kubis Merah; Pewarna Makanan Alami; Antosianin, Cheesecake

\section{ABSTRACT}

Anthocyanin is a color pigment in plants that also has antioxidant activity. Anthocyanins can be found in blue or red plants such as red cabbage. One of the efforts to increase antioxidants in food is by adding anthocyanin extracts from plants into the food as natural dyes. Cake is one of kind of food products that can be added coloring agent. Cheesecake which is added with red cabbage extract can be a favorite food because it contains an attractive appearance and has antioxidant benefits. The purpose of this study was to determine the effect of adding red cabbage extract powder to the chemical, physical, microbiological, and organoleptic qualities of cheesecake and also to determine the best concentration of the extract. The experimental design used in this study was a Completely Randomized Design (CRD) with variations of red cabbage extract $0 \%$ (control), $5 \%(A), 10 \%(B)$, and $15 \%(C)$. The results of this study showed that cheesecake with variations in the addition of red cabbage extract powder has a 
Jurnal Teknologi Pertanian Vol. 22 No. 3 [Desember 2021] 221-236

Penambahan Bubuk Ekstrak Kubis Merah Sebagai Sumber Antioksidan dan Pewarna Alami Pada Cheesecake

[Wuwur dkk]

moisture content of $42.38-49.06 \%$, ash content $0.64-0.84 \%$, protein content $4.57-4.81 \%$, fat content 27.17-31.85\%, carbohydrate content $13.98-24.90 \%$, total phenolic 0.76-1.16 mg GAE / g DW, antioxidant activity 27.27-55.58\%, TAT 0.01-0.02\% and microbiological tests consisting of Salmonella tests and total plate count already met the standards set by USDA (United State Department of Agriculture) and BSN (Badan Standardisasi Nasional). Organoleptic results showed that cheesecake A $(5 \%)$ was the most preffered product by panelists

Keywords: Red Cabbage Extract Powder; Natural Food Dye; Anthocyanin; Cheesecake

\section{PENDAHULUAN}

Cheesecake atau kue keju merupakan salah satu kue yang cukup digemari sekarang. Cheesecake dapat diterima oleh masyarakat dengan tingkat penerimaan 83\% (Kalukiningrum, 2012). Cheesecake dengan kualitas baik mempunyai tekstur lembut, tebal, dan padat, serta memiliki rasa dan bau seperti keju (USDA, 2005). Kualitas kimia, fisik, organoleptik, dan mikrobiologi pada cheesecake diharapkan dapat meningkat dengan adanya penambahan bubuk ekstrak kubis merah sebagai pewarna alami, sehingga lebih disukai dan memiliki manfaat sebagai antioksidan.

Antioksidan merupakan senyawa yang dapat menahan, menghilangkan dan membersihkan efek dari radikal bebas yang dapat menyebabkan berbagai penyakit degeneratif seperti penuaan dini, penyakit jantung, stroke, katarak, osteoarthritis, dan kanker (Dwipayanti et al., 2020; Khaira, 2010). Salah satu jenis antioksidan yang dapat ditemui pada kubis merah adalah antosianin.

Antosianin merupakan senyawa flavonoid yang berfungsi sebagai antioksidan (Jiao et al., 2012; Takahata et al., 2011). Antosianin merupakan pigmen yang memiliki cakupan warna yang luas yaitu biru, biru agak kehijauan, ungu, jingga, dan merah (Ondagau et al., 2019). Antosianin terdapat pada cairan sel tumbuhan dan dapat larut dalam air (Santoso dan Estiasih, 2014). Antosianin dapat dimanfaatkan sebagai alternatif pewarna pada produk pangan dan obat (He et al., 2015). Hal ini mendasari penelitian penambahan bubuk ekstrak kubis merah yang memiliki potensi sebagai pewarna alami pada bahan makanan. Pemberian pewarna alami dari bubuk ekstrak kubis merah ke dalam cheesecake diharapkan dapat meningkatkan daya tarik dan daya jual cheesecake, serta dapat sebagai sumber antioksidan bagi setiap yang mengkonsumsi.

\section{METODE}

Alat-alat yang digunakan pada penelitian ini meliputi LFRA texture analyzer Brookefield, laminar air flow (LAF) ESCO AVS-3A1 dan SV 1200 SG, moisture balancing Phoenix Instrumen, spray drying Buchi, cawan alumunium, oven Cosmoven, timbangan digital Acis, timbangan analitik Phoenix Instrumen, autoklaf Hirayama HIC LIVE/HVE-50, soxhlet Sopod, perangkat kjeldahl, tanur One Tech, eksikator, inkubator Memmert, color reader Konica Minolta, spektrofotometer UV-1800 Shimadzu, kuvet kaca Uv-Vis, alat sentrifugasi Harmonic Series, lemari asam Biobase, jarum ose, mikrotip, vortex RSVSA10, kulkas Sharp dan mikropipet.

Bahan-bahan yang dibutuhkan pada penelitian ini antara lain kubis merah (Brassica oleraceae var. capitata f. rubra) yang berasal dari toko sayur organik Say Fresh Yogyakarta, maltodekstrin, akuades, asam sitrat, cling wrap, larutan blanko, medium Salmonella Shigella Agar (SSA), medium Lactose Broth (LB), medium Selenite Cystine Broth (SCB), heksana, etanol 70\%, indikator metil merah, $\mathrm{NaOH} 40 \%$, larutan $\mathrm{H}_{2} \mathrm{SO}_{4}$ pekat, asam askorbat, katalis $\mathrm{N}$, asam borat, indikator MRBCG, $\mathrm{HCl} \mathrm{PA,}$ asam galat, larutan $\mathrm{Na}_{2} \mathrm{CO}_{3} 7,5 \%, \mathrm{NaOH}$ $0,1 \mathrm{~N}$, medium Plate Count Agar (PCA), reagen Folin-Ciocalteu, dan DPPH (2,2diphenyl-1-picrylhydrazyl). 


\section{Pembuatan Bubuk Ekstrak Kubis Merah}

Pembuatan bubuk ekstraksi kubis merah menggunakan metode maserasi dengan perbandingan antara bubuk kubis merah dan pelarut aquades adalah 1:10, mengacu pada Prasetya et al. (2020) dan Arisandi (2001). Maserasi dilakukan dengan merendam kubis merah pada aquades yang telah ditambah asam sitrat 0,75\% dengan suhu $80-90{ }^{\circ} \mathrm{C}$ selama 1 jam, kemudian proses maserasi dilanjutkan pada chiller dengan suhu $4{ }^{\circ} \mathrm{C}$ selama 24 jam. Bubuk ekstrak kubis merah cair selanjutnya dibuat menjadi bubuk kering menggunakan spray drying dengan konsentrasi maltodekstrin $5 \%$ dan suhu inlet $130^{\circ} \mathrm{C}$.

\section{Uji Bahan Awal}

Kualitas bahan awal ditentukan dengan beberapa uji, yaitu uji kadar air, kadar abu, total asam tertitrasi, total fenolik, aktivitas antioksidan, dan total antosianin. Kadar air diuji dengan alat moisture analyzer (Sembiring, 2009). Kadar abu diketahui dengan menghitung selisih antara berat sampel sebalum dimasukkan ke dalam tanur dan berat sampel setelah 8 jam dipanaskan dalam tanur suhu $550{ }^{\circ} \mathrm{C}$. Total asam tertitrasi dihitung dengan melakukan titrasi pada $10 \mathrm{ml}$ sampel dengan titran $\mathrm{NaOH}$ 0,1 N (AOAC, 1995).

Total fenolik diuji dengan metode Folin-Ciocalteu. Absorbansi larutan sampel akan dibandingkan dengan absorbansi kurva standar asam galat. Pelarut yang digunakan adalah etanol $70 \%$ dan pengukuran absorbansi dilakukan pada panjang gelombang $765 \mathrm{~nm}$ (Barku et al., 2013). Aktivitas antioksidan diuji dengan dengan metode DPPH. Perbandingan sampel dan DPPH adalah 1:1, dengan pelarut etanol $70 \%$. Aktivitas antioksidan untuk menghambat radikal bebas DPPH dapat dihitung dengan mengetahui absorbansi sampel menggunakan spektrofotometer UV-Vis dengan panjang gelombang $517 \mathrm{~nm}$ (Hasanah et al., 2017; Rauf et al., 2010).

Uji total antosianin dilakukan dengan metode $\mathrm{pH}$ diferensial. Larutan buffer yang digunakan adalah kalium klorida atau potassium chloride $(\mathrm{KCl}) \mathrm{pH} 1,0$ dengan molaritas 0,025 dan natrium asetat atau sodium acetate $\left(\mathrm{NaC}_{2} \mathrm{H}_{3} \mathrm{O}_{2}\right)$ pH 4,5 dengan molaritas 0,4 . Total antosianin dapat dihitung dengan mengetahui absorbansi sampel menggunakan spektrofotometer UV-Vis dengan panjang gelombang $510 \mathrm{~nm}$ dan $700 \mathrm{~nm}$ (AOAC, 2005).

\section{Pembuatan Produk Cheesecake}

Chessecake dibuat dengan bahanbahan yang terdiri dari $400 \mathrm{~g}$ cream cheese, $120 \mathrm{~g}$ gula, $200 \mathrm{~g}$ sour cream dan $150 \mathrm{ml}$ heavy cream, kemudian dihomogenkan dengan wisk hingga rata. Telur sebanyak $100 \mathrm{~g}$ ditambahkan ke dalam adonan kemudian diaduk hingga rata. Tepung maizena sebanyak $8 \mathrm{~g}$ dan ekstrak vanilla sebanyak $5 \mathrm{ml}$ ditambahkan kedalam adonan. Selanjutnya, adonan dibagi menjadi 4 bagian dan pada masing-masing adonan ditambahkan serbuk ekstrak kubis merah sebanyak $0 \%, 5 \%, 10 \%$ dan $15 \%$ dari berat adonan.

Adonan cheesecake kemudian dipanggang dengan teknik au bain marie. Adonan dipanggang pada oven suhu 180 ${ }^{\circ} \mathrm{C}$ selama 30 menit, kemudian dilanjutkan dengan suhu $150{ }^{\circ} \mathrm{C}$ selama 30 menit. Cheesecake yang telah dipanggang lalu dimasukkan ke dalam chiller selama 8 jam agar adonan padat (Yasin dan Shalaby, 2013).

\section{Uji Produk Cheesecake dengan Variasi Penambahan Bubuk Ekstrak Kubis Merah Kualitas produk cheesecake} ditentukan dengan uji proksimat, total fenolik, aktivitas antioksidan, analisis warna dan tekstur, serta uji mikrobiologi. Uji kadar air, abu, total asam tertitrasi (TAT), total, fenolik, dan aktivitas antioksidan dilakukan dengan cara yang sama seperti uji pada bahan awal. Kadar protein sampel ditentukan dengan metode mikro Kjeldhal. Uji kadar lemak pada sampel menggunakan metode sokhlet dengan pelarut heksana. Kadar karbohidrat sampel ditentukan dengan metode by difference.

$$
\text { Analisis warna dilakukan }
$$
menggunakan alat color reader dengan sistem Lab CIE Hunter (deMan, 1999). 
Jurnal Teknologi Pertanian Vol. 22 No. 3 [Desember 2021] 221-236

Penambahan Bubuk Ekstrak Kubis Merah Sebagai Sumber Antioksidan dan Pewarna Alami Pada Cheesecake

[Wuwur dkk]

Analisis tekstur produk dilakukan dengan alat texture analyzer. Probe yang digunakan adalah TA 41. Parameter tekstur yang diuji adalah kekerasan produk yang dianalisis menggunakan program Texture ProLite (Chandra et al., 2021; Saputri et al., 2021; Martin-Diana et al., 2017). Kualitas produk secara mikrobiologi ditentukan oleh angka lempeng total (ALT) dan keberadaan Salmonella sp. Uji angka lempeng total produk menggunakan metode pour plate dengan pengenceran sampel $10^{-1}$ hingga $10^{-5}$ (BSN, 2006). Uji keberadaan Salmonella sp. dilakukan dengan metode streak plate (BSN, 2015).

\section{Uji Organoleptik}

Uji organoleptik dilakukan dengan menghitung tingkat kesukaan dari 30 panelis (15 pria dan 15 wanita) dengan memberikan nilai 1-4 (1 paling tidak disukai dan 4 paling disukai).

\section{HASIL DAN PEMBAHASAN}

\section{Kualitas Bubuk Ekstrak Kubis Merah}

Bubuk ekstrak kubis merah (Gambar

1) sebagai bahan awal dilakukan uji pendahuluan untuk menentukan kandungan di dalamnya. Bubuk ekstrak kubis merah mempunyai kadar air sebesar $9,16 \%$. Hasil tersebut berbeda dengan penelitian dari Rahardjo (2018) yang menyatakan bubuk ekstrak kubis merah memiliki kadar air sebesar 7,84\%. Perbedaan ini dapat disebabkan oleh metode pembuatan bubuk ekstrak yang berbeda. Pembuatan bubuk pada penelitian ini dilakukan dengan metode spray drying, sedangkan pada penelitian Rahardjo (2018) dilakukan dengan metode cabinet drying. Maltodekstrin pada bubuk ekstrak memiliki sifat higroskopis sehingga dapat mengikat air di sekitarnya (Permatasari dan Afifah, 2020).

Kadar abu bubuk ekstrak kubis merah sebesar 1,09\%. Hasil ini tidak sesuai dengan penelitian dari Tze et al. (2012) yang menyatakan bahwa ekstrak bubuk buah naga dengan penambahan maltodekstrin sebanyak 20\% dan dikeringkan dengan suhu spray drying $155{ }^{\circ} \mathrm{C}$ mempunyai kadar abu sebesar 0,79\%. Ketidaksesuaian ini dapat disebabkan oleh adanya perbedaan suhu dan konsentrasi maltodekstrin yang digunakan saat proses spray drying serta perbedaan bahan baku yang digunakan. Menurut Ashfaq et al. (2018) dan Nurul dan Asmah (2014), buah naga memiliki kandungan kadar abu berkisar antara 0,54$1,19 \%$ tergantung dari jenis dan asal buah naga tersebut, sedangkan kubis merah memiliki kadar abu sebesar 0,87\%. Hasil kadar abu bubuk ekstrak kubis merah yang terukur merupakan kadar abu total, sehingga kadar abu yang didapatkan adalah total kandungan mineral pada maltodekstrin dan kubis merah. Kadar abu maksimal pada maltodekstrin menurut BSN (Badan Standardisasi Nasional) sebesar $0,5 \%$.

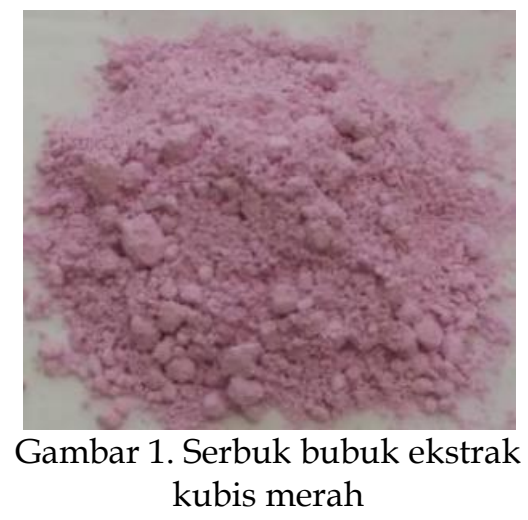

Hasil total fenolik bubuk ekstrak kubis merah sebesar $211 \mathrm{mg}$ GAE/100 g DW. Hasil ini sesuai dengan penelitian Karoui et al. (2018) yang menyatakan kandungan total fenolik pada bubuk ekstrak kubis merah adalah sebanyak 190,77-205,66 mg GAE/100 g DW. Senyawa fenolik yang terdapat pada kubis putih dan merah dapat berupa 3-O- sophoroside-7-Oglucoside, asam sinapik, kafeik, ferulik, dan antosianin (Izzo et al., 2020; Mazza dan Miniati, 2018).

Kubis merah memiliki senyawa fenolik berupa asam galat, asam tanat, hidrat katekin, asam 3,4-dihidroksibenzoat, asam rosmarinat, asam ferulat, naringin, luteolin, dan flavonol. Senyawa fenolik yang paling dominan pada kubis merah 
adalah asam ferulat dengan konsentrasi sebesar $40,03 \%$ dari kandungan total fenolik pada kubis merah, serta memiliki ketahanan panas yang baik karena titik leleh senyawa ini berada pada suhu $168-171{ }^{\circ} \mathrm{C}$. Senyawa fenolik pada kubis merah yang lain juga memiliki ketahanan panas yang cukup baik yaitu asam tanat dengan titik leleh $200{ }^{\circ} \mathrm{C}$, asam rosmarinat memiliki titik leleh $171-175{ }^{\circ} \mathrm{C}$, dan luteolin memiliki titik leleh 329,5 ${ }^{\circ} \mathrm{C}$ (Karoui et al., 2018). Kandungan fenolik pada bubuk ekstrak kubis merah juga dienkapsulasi oleh maltodekstrin yang dapat melindungi senyawa dari pengaruh luar seperti pemanasan.

Aktivitas antioksidan pada bubuk ekstrak kubis merah sebesar $84,69 \%$. Hasil tersebut sesuai dengan penelitian Karoui et al. (2018) yang menyatakan bahwa antivitas antioksidan pada bubuk ekstrak kubis merah berkisar antara 80-93,89\%. Aktivitas antioksidan kubis merah berasal dari senyawa fenolik, a-tokoferol, asam askorbat, dan karotenoid yang ada pada kubis merah (Podsędek et al., 2006).

Uji total antosianin dilakukan untuk menentukan batas penambahan bubuk ekstrak kubis merah ke dalam adonan cheesecake. Hasil uji total antosianin pada bubuk kubis merah adalah 466,73 mg/100 g. Berdasarkan hasil tersebut diketahui bahwa 1000 g adonan cheesecake dengan penambahan konsentrasi bubuk ekstrak kubis merah tertinggi (15\%) akan mendapat tambahan antosianin sekitar 700,09 mg. Hasil ini sesuai dengan batas maksimum penambahan pewarna antosianin ke dalam produk bakery istimewa yang ditetapkan oleh BPOM (2013), yaitu maksimal sebanyak $1.500 \mathrm{mg} / 1.000 \mathrm{~g}$ adonan. Berdasarkan hasil ini juga dapat diketahui bahwa produk cheesecake dengan penambahan bubuk ekstrak kubis merah tertinggi (15\%) dapat dikonsumsi maksimal sebanyak 2142,57 g (1 potong cheesecake memiliki berat $100 \mathrm{~g}$ ).

Analisis warna pada bubuk ekstrak kubis merah didapatkan nilai L sebesar 75,23; nilai a sebesar 20,82; dan nilai b sebesar -2,12. Hasil ini menunjukkan bahwa bubuk ekstrak kubis merah memiliki warna yang mengarah pada warna ungu (campuran warna merah dan biru), serta memiliki tingkat kecerahan yang cukup tinggi. Nilai $\mathrm{L}$ menunjukkan tingkat kecerahan $(\mathrm{L}=100$ menunjukkan warna putih, sedangkan nilai $\mathrm{L}=0$ menunjukkan warna hitam), nilai a menunjukkan warna merah atau hijau (nilai a tinggi (+a) mengarah ke warna merah, sedangkan jika nilai a rendah (-a) mengarah ke warna hijau), nilai $b$ menunjukkan warna kuning atau biru (nilai b tinggi $(+b)$ mengarah ke warna kuning, sedangkan jika nilai $b$ rendah (-b) akan mengarah kewarna biru) (deMan, 1999). Hasil yang didapat sesuai dengan penampakan visual bubuk ekstrak yang berwarna ungu terang.

\section{Kualitas Kimia Penambahan Bubuk Ekstrak Kubis Merah pada Cheesecake \\ Uji kualitas kimia terdiri dari uji} kadar air, abu, protein, lemak, karbohidrat, dan total asam tertitrasi. Hasil uji kimia penambahan bubuk ekstrak kubis merah pada cheesecake dapat dilihat pada Tabel 1. Kadar air cheesecake kontrol dan cheesecake dengan variasi penambahan bubuk ekstrak kubis merah berada pada kisaran 42,38$49,06 \%$. Kadar air produk cheesecake telah memenuhi standar yang ditetapkan oleh USDA (United State Department of Agriculture) yaitu maksimal 60\%.

Kadar air produk cenderung mengalami penurunan seiring dengan bertambahnya konsentrasi bubuk ekstrak kubis merah. Hasil ini sesuai dengan penelitian dari Badola et al. (2017) yang menyatakan bahwa semakin tinggi penambahan konsentrasi maltodekstrin pada produk khoa menyebabkan kadar air produk semakin rendah. Penurunan kadar air dapat disebabkan oleh pengaruh maltodekstrin pada bubuk ekstrak kubis merah.

Pembuatan bubuk ekstrak dilakukan dengan metode spray drying menggunakan bahan mikroenkapsulasi maltodekstrin. Maltodekstrin merupakan karbohidrat yang dapat dicerna tubuh dengan mudah dan terbuat dari pati. Air yang berikatan dengan makromolekul akan menyebabkan sifat air berubah menjadi tidak dapat membeku dan sulit dihilangkan selama proses pengeringan (Suryani dan Nisa, 2015). 
Jurnal Teknologi Pertanian Vol. 22 No. 3 [Desember 2021] 221-236

Penambahan Bubuk Ekstrak Kubis Merah Sebagai Sumber Antioksidan dan Pewarna Alami Pada Cheesecake

[Wuwur dkk]

Tabel 1. Kualitas kimia penambahan bubuk ekstrak kubis merah pada cheesecake

\begin{tabular}{ccccccc}
\hline $\begin{array}{c}\text { Bubuk } \\
\text { Ekstrak } \\
(\%)\end{array}$ & $\begin{array}{c}\text { Kadar Air } \\
\mathbf{( \% )}\end{array}$ & $\begin{array}{c}\text { Kadar Abu Kadar Protein } \\
\mathbf{( \% )}\end{array}$ & $\begin{array}{c}\text { Kadar Lemak } \\
\mathbf{( \% )}\end{array}$ & $\begin{array}{c}\text { Kadar Karbohidrat } \\
\mathbf{( \% )}\end{array}$ & $\mathbf{( \% )}$ & \\
\hline $0(\mathrm{~K})$ & $49,06 \mathrm{~d}$ & $0,64 \mathrm{a}$ & $4,57 \mathrm{a}$ & $31,85 \mathrm{c}$ & $13,98 \mathrm{a}$ & $0,01 \mathrm{a}$ \\
$5(\mathrm{~A})$ & $48,47 \mathrm{c}$ & $0,85 \mathrm{~b}$ & $4,64 \mathrm{a}$ & $29,58 \mathrm{~b}$ & $16,54 \mathrm{~b}$ & $0,02 \mathrm{a}$ \\
$10(\mathrm{~B})$ & $44,84 \mathrm{~b}$ & $0,87 \mathrm{~b}$ & $4,69 \mathrm{ab}$ & $29,41 \mathrm{~b}$ & $20,28 \mathrm{c}$ & $0,02 \mathrm{a}$ \\
$15(\mathrm{C})$ & $42,38 \mathrm{a}$ & $0,84 \mathrm{~b}$ & $4,81 \mathrm{~b}$ & $27,17 \mathrm{a}$ & $24,90 \mathrm{~d}$ & $0,02 \mathrm{a}$ \\
\hline
\end{tabular}

*Nilai yang diikuti huruf yang sama pada kolom menunjukkan tidak adanya beda nyata $(\alpha=0,05$; tingkat kepercayaan 95\%)

Hal ini menyebabkan air yang berikatan dengan maltodekstrin sulit untuk diuapkan, sehingga cheesecake dengan konsentrasi maltodekstrin tinggi memiliki kadar air rendah.

Kadar abu cheesecake kontrol dan cheesecake dengan variasi penambahan bubuk ekstrak kubis merah berada pada kisaran 0,64$0,87 \%$. Kadar abu produk memenuhi standar yang ditetapkan oleh USDA, yaitu maksimal sebanyak $0,9 \%$. Kadar abu pada penelitian ini diuji menggunakan metode langsung yang dapat menghitung total mineral. Menurut (Maulana, 2016), abu yang terhitung merupakan total mineral dari bahan baku, dalam hal ini adalah dari bubuk ekstrak kubis merah dan bahan baku lain untuk pembuatan cheesecake.

Penambahan bubuk ekstrak kubis merah pada cheesecake menyebabkan kadar abu produk cenderung mengalami peningkatan seiring dengan penambahan konsentrasi bubuk ekstrak. Peningkatan ini terjadi karena adanya kandungan abu pada bahan awal (bubuk ekstrak kubis merah) sebesar 1,09\% sehingga dengan meningkatnya penambahan bubuk ekstrak maka kadar abu juga semakin meningkat. Cheesecake kontrol memiliki kadar abu terendah, yaitu 0,64\%. Hal ini dapat dikarenakan cheesecake kontrol tidak mendapat perlakuan penambahan bubuk ekstrak kubis merah, sehingga kadar abu yang terhitung pada cheesecake kontrol hanya berasal dari bahan baku pembuat cheesecake yang mengandung mineral. Klaim kandungan mineral pada kemasan cream cheese Anchor adalah $0,092 \%$ kalsium dan $0,284 \%$ sodium, sour cream Yummy sebanyak 0,02\% sodium, dan pada whipping cream Anchor mengandung $0,027 \%$ sodium.
Kadar protein cheesecake kontrol dan cheesecake dengan variasi penambahan bubuk ekstrak kubis merah berada pada kisaran 4,57$4,81 \%$. Kadar protein produk cheesecake telah memenuhi standar yang ditetapkan oleh USDA, yaitu berkisar antara 3,94-5,5\%. Penambahan bubuk ekstrak kubis merah pada cheesecake menyebabkan kadar protein produk cenderung mengalami peningkatan seiring dengan penambahan bubuk ekstrak. Hal ini dikarenakan kubis merah mengandung protein pada kisaran 1,04-1,52\% (Adelanwa dan Medugu, 2015). Protein dari kubis merah merupakan protein nabati yang berasal dari tumbuhan. Beberapa asam amino penyusun protein yang ditemui pada kubis merah, yaitu glutamin sebesar 292,9 mg/100 g, glisin sebesar $37,6 \mathrm{mg} / 100 \mathrm{~g}$, dan arginin sebesar 23,3 mg/ $100 \mathrm{~g}$ (Park et al., 2014).

Cheesecake kontrol memiliki kadar protein terendah $(4,57 \%)$. Protein yang terdapat pada cheesecake kontrol dapat berasal dari bahan baku pembuatan cheesecake. Telur ayam ras sebanyak $25 \mathrm{~g}$ memiliki kadar protein sebanyak 3,125 g (Zein dan Newi, 2019), whipped cream Anchor yang digunakan dalam penelitian ini mencantumkan bahwa sebanyak $40 \mathrm{ml}$ whipped cream memiliki kadar protein sebesar 0,96 g, sour cream Yummy mencantumkan bahwa sebanyak $50 \mathrm{~g}$ sour cream mengandung protein sebanyak $2 \mathrm{~g}$, serta cream cheese Anchor mencantumkan bahwa sebanyak $100 \mathrm{~g}$ cream cheese mengandung protein sebanyak $8,8 \mathrm{~g}$.

Kadar lemak cheesecake kontrol dan cheesecake dengan variasi penambahan bubuk ekstrak kubis merah berada pada kisaran $27,17-31,85 \%$. Kadar lemak produk cheesecake telah memenuhi standar yang ditetapkan oleh USDA, yaitu minimal $27 \%$. 
Penambahan bubuk ekstrak kubis merah pada cheesecake menyebabkan kadar lemak produk yang cenderung menurun dengan bertambahnya konsentrasi bubuk ekstrak. Hal ini dapat dikarenakan bubuk ekstrak kubis merah tidak mempunyai kandungan lemak, sehingga adanya penambahan bubuk ekstrak kubis merah pada adonan cheesecake akan menyebabkan berat adonan bertambah. Namun demikian, hal ini tidak menambah kadar lemak pada produk, sehingga kadar lemak cheesecake akan semakin rendah seiring dengan adanya penambahan bubuk ekstrak kubis merah.

Kadar karbohidrat cheesecake kontrol dan cheesecake dengan variasi penambahan bubuk ekstrak kubis merah berada pada kisaran 13,98-24,90\%. Kadar karbohidrat produk cheesecake telah sesuai dengan standar yang ditetapkan oleh USDA dan penelitian dari Yasin dan Shalaby (2013), yaitu berkisar antara 10,28-25,50\%. Penambahan bubuk ekstrak kubis merah menyebabkan kadar karbohidrat cheesecake mengalami peningkatan seiring dengan penambahan konsentrasi bubuk ekstrak. Hal ini dapat disebabkan oleh adanya kandungan maltodekstrin di dalam bubuk ekstrak kubis merah.

Maltodekstrin merupakan karbohidrat dalam golongan polisakarida yang diproduksi dari hidrolisis asam atau enzimatik pati yang memiliki kandungan 4 kalori per gram (Kumalaningsih, 2014). Semakin banyak jumlah bubuk ekstrak kubis merah yang ditambahkan dalam produk cheesecake, maka kandungan maltodekstrin juga akan meningkat, sehingga kadar karbohidrat pada cheesecake mengalami peningkatan seiring dengan bertambahnya bubuk ekstrak.

Cheesecake kontrol $(0 \%)$ memiliki kadar karbohidrat terendah (13,98\%). Karbohidrat yang terdapat pada cheesecake dapat berasal dari bahan baku pembuat cheesecake. Klaim kandungan karbohidrat pada kemasan cream cheese Anchor adalah 2,5\%, sour cream Yummy sebanyak $2 \%$, whipping cream Anchor mengandung 3,1\% karbohidrat, dan tepung maizena mengandung karbohidrat $89 \%$.

Penambahan bubuk ekstrak kubis merah pada cheesecake menyebabkan total asam tertitrasi pada produk cenderung mengalami peningkatan seiring dengan adanya penambahan konsentrasi bubuk ekstrak. Hal ini disebabkan oleh adanya penambahan asam sitrat pada saat proses maserasi ekstrak kubis merah, sehingga penambahan bubuk ekstrak pada cheesecake akan menambah total asam pada produk. Total asam tertitrasi terendah adalah cheesecake kontrol $(0,01 \%)$. Asam yang terdapat pada cheesecake kontrol dapat berasal dari sour cream yang merupakan salah satu bahan baku pembuatan cheesecake. Asam organik yang terkandung pada sour cream yaitu asam format, asam laktat, asam piruvat, asam orotat, asam asetat, asam urat, asam sitrat, dan asam butirat. Jumlah kandungan asam pada sour cream bergantung pada jenis sour cream tersebut (Shepard et al., 2013).

\section{Kualitas Antioksidan Penambahan Bubuk Ekstrak Kubis Merah pada Cheesecake}

Kualitas antioksidan pada produk dapat diketahui dengan uji total fenolik dan uji aktivitas antioksidan dengan metode DPPH. Hasil uji dapat dilihat pada Tabel 2. Total fenolik cheesecake kontrol dan cheesecake dengan variasi penambahan bubuk ekstrak kubis merah berada pada kisaran 0,76-1,16 mg GAE/g DW. Total fenolik produk cheesecake telah sesuai dengan penelitian Lucera et al. (2018), yaitu sebesar 0,66 mg GAE/g DW.

Penambahan bubuk ekstrak kubis merah menyebabkan total fenolik pada produk cheesecake cenderung meningkat seiring dengan penambahan konsentrasi bubuk ekstrak. Peningkatan ini terjadi karena adanya kandungan fenolik pada bubuk ekstrak kubis merah sebesar $211 \mathrm{mg}$ GAE/100 g DW. Jenis senyawa fenolik yang terdapat pada kubis merah berdasarkan Karoui et al. (2018) adalah asam galat, asam tanat, hidrat katekin, asam 3,4-dihidroksibenzoat, asam rosmarinat, naringin, luteolin dan flavonol. Cheesecake kontrol memiliki total fenolik terendah karena tidak mendapat tambahan bubuk ekstrak. Kandungan total fenolik pada cheesecake kontrol dapat berasal dari bahan baku pembuatan cheesecake seperti keju yang memiliki sedikit kandungan fenolik, sehingga aktivitas antioksidannya rendah dan terbatas (Han et al., 2011).

Aktivitas antioksidan pada produk A mengalami peningkatan sebesar $62,30 \%$, produk B sebesar 74,59\% dan produk C sebesar 103,81\%. Peningkatan aktivitas antioksidan produk cheesecake berbanding lurus dengan peningkatan total fenolik. Peningkatan aktivitas antioksidan pada produk lebih tinggi dibandingkan peningkatan total fenoliknya. 
Jurnal Teknologi Pertanian Vol. 22 No. 3 [Desember 2021] 221-236

Penambahan Bubuk Ekstrak Kubis Merah Sebagai Sumber Antioksidan dan Pewarna Alami Pada Cheesecake [Wuwur dkk]

Tabel 2. Aktivitas antioksidan penambahan bubuk ekstrak kubis merah pada cheesecake

\begin{tabular}{ccc}
\hline Bubuk Ekstrak (\%) & Total Fenolik (mg GAE/g DW) & Aktivitas Antioksidan (\%) \\
\hline $0(\mathrm{~K})$ & $0,76 \mathrm{a}$ & $27,27 \mathrm{a}$ \\
$5(\mathrm{~A})$ & $0,84 \mathrm{a}$ & $44,26 \mathrm{~b}$ \\
$10(\mathrm{~B})$ & $1,00 \mathrm{~b}$ & $47,61 \mathrm{~b}$ \\
$15(\mathrm{C})$ & $1,16 \mathrm{c}$ & $55,58 \mathrm{c}$ \\
\hline
\end{tabular}

*Nilai yang diikuti huruf yang sama pada kolom menunjukkan tidak adanya beda nyata ( $\mathrm{a}=0,05$ tingkat kepercayaan 95\%)

Hal ini menurut Pereira et al. (2009) disebabkan oleh senyawa antioksidan yang terbaca pada uji total fenolik adalah senyawa yang memiliki gugus hidroksil yang berikatan dengan cicin fenil. Beberapa senyawa antioksidan yang terdapat pada kubis merah seperti karotenoid tidak memiliki struktur seperti fenolik, sehingga tidak terbaca pada uji total fenolik (Załuski et al., 2015).

Aktivitas antioksidan menghambat radikal bebas (DPPH), pada produk cheesecake kontrol dan cheesecake dengan variasi penambahan bubuk ekstrak kubis merah, berada pada kisaran 27,27-55,58\%. Aktivitas antioksidan pada cheesecake belum diketahui, namun berdasarkan penelitian dari (Nugroho et al., 2018), aktivitas antioksidan pada keju adalah sebesar 22,32\%. Penambahan bubuk ekstrak kubis merah pada cheesecake menyebabkan aktivitas antioksidan produk cenderung meningkat seiring dengan adanya penambahan bubuk ekstrak kubis merah. Pengujian aktivitas antioksidan cheesecake dan bubuk ekstrak kubis merah pada penelitian ini menggunakan metode dan formulasi (1:1) yang sama. Peningkatan ini terjadi karena adanya aktivitas antioksidan pada bubuk ekstrak kubis merah sebesar $84,69 \%$.

Aktivitas antioksidan pada bubuk ekstrak kubis merah dapat berasal dari seyawa fenolik, a-tokoferol, asam askorbat, dan karatenoid yang ada pada kubis merah. Selain itu, antosianin pada kubis merah juga cukup tinggi, berkisar antara 40,53-76,16 mg/100 g kubis merah. Menurut Podsędek et al. (2006), tingginya kandungan antosianin tergantung pada jenis kubis merah. Antosianin dapat berperan dalam menghambat radikal bebas DPPH dengan cara melakukan donor hidrogen terhadap radikal bebas, sehingga terbentuk DPPH yang bersifat tidak radikal. Proses ini ditandai dengan perubahan warna ungu menjadi warna kuning (Molyneux, 2004). Aktivitas antioksidan pada cheseecake juga berasal dari dairy product yang merupakan bahan baku pembuatan cheesecake. Aktivitas antioksidan pada dairy product dapat berasal dari senyawa fenolik, kasein, karatenoid, whey protein, vitamin E, asam askorbat, katalase dan glutathione peroxidase (Khan et al., 2019).

Tabel 3. Perbandingan aktivitas antioksidan penambahan bubuk ekstrak kubis merah pada chessecake dan vitamin C

\begin{tabular}{lc}
\hline Produk Uji & $\begin{array}{c}\text { Aktivitas Antioksidan } \\
(\mathbf{\%})\end{array}$ \\
\hline Cheesecake C (15\%) & $55,58 \pm 2,99 \mathrm{a}$ \\
Vitamin C & $94,50 \pm 0,00 \mathrm{~b}$ \\
\hline
\end{tabular}

${ }^{*}$ Nilai yang diikuti huruf yang sama pada kolom menunjukkan tidak adanya beda nyata $(\mathrm{a}=0,05$ tingkat kepercayaan 95\%)

Perbandingan aktivitas antioksidan dilakukan pada produk cheesecake C (15\%) yang memiliki total fenolik dan aktivitas antioksidan tertinggi dengan vitamin $C$ pada konsentrasi yang sama, yaitu 40,77 ppm. Aktivitas antioksidan pada vitamin $\mathrm{C}$ lebih tinggi dari pada cheesecake $\mathrm{C}$ (Tabel 3). Hal ini dikarenakan vitamin $\mathrm{C}$ bersifat murni dan memiliki aktivitas antioksidan tinggi $(94,50 \%)$. Vitamin C dapat mendonorkan dua elektron untuk mencegah oksidasi, serta dapat mendonorkan hidrogen dan membentuk radikal ascorbyl yang stabil (Pehlivan, 2017). 
Proses pemanggangan cheesecake dapat menurunkan aktivitas antioksidan karena beberapa senyawa antioksidan seperti antosianin dapat menurun jika terkena panas tinggi. Senyawa antosianin pada kubis merah yang tidak stabil pada suhu tinggi disebut antosianin tidak terasilasi misalnya cyanidin-3diglucosidase-5-glucosidase. Beberapa senyawa antosianin pada kubis merah yang stabil pada suhu tinggi atau senyawa antosianin yang terasilasi, misalnya cyanidin-3-diglucosidase- 5glucosidase+ferulic dan cyanidin-3- diglucosidase5-glucosidase+sinapic +ferulic (Ahmadiani et al., 2014; Lukitasari et al., 2017).

Senyawa antosianin yang terasilasi merupakan senyawa antosianin dominan pada kubis merah. Senyawa cyanidin-3- diglucosidase5-glucosidase+ferulic memiliki konsentrasi sebesar 13,10 mg/100 g kubis merah dan konsentrasi dari cyanidin-3- diglucosidase-5glucosidase+sinapic +ferulic sebesar 11,74 $\mathrm{mg} / 100 \mathrm{~g}$ kubis merah (podsedek et al., 2014). Senyawa antosianin pada kubis merah dapat stabil pada suhu $80{ }^{\circ} \mathrm{C}$ dan akan mengalami degradasi sebasar $6 \%$ pada suhu $100{ }^{\circ} \mathrm{C}$ selama 60 menit. Degradasi antosianin akan meningkat seiring dengan terjadinya peningkatan suhu waktu pemanasan, namun senyawa antosianin yang mengalami asilasi dengan asam ferulat, asam sinapat, dan asam p-kumarat akan lebih stabil pada suhu tinggi karena titik leleh asam ferulat berada pada suhu $168-171{ }^{\circ} \mathrm{C}$, asam sinapat pada suhu 192 ${ }^{\circ} \mathrm{C}$, dan asam p-kumarat berada pada suhu $211,5^{\circ} \mathrm{C}$ (Rizk et al., 2009).

\section{Kualitas Fisik Penambahan Bubuk Ekstrak Kubis Merah pada Cheesecake}

Kualitas fisik produk diuji dengan analisa tekstur (kekerasan) dan warna. Hasil uji kualitas fisik produk dapat dilihat pada
Tabel 4. Kekerasan cheesecake kontrol dan cheesecake dengan variasi penambahan bubuk ekstrak kubis merah berada pada kisaran 94,83-224,33 g. Tidak ada standar untuk tekstur produk cheesecake, namun berdasarkan USDA (2005), New York cheesecake mempunyai tekstur lembut, tebal, dan padat. Hasil analisis kekerasan cenderung mengalami penurunan seiring dengan adanya penambahan bubuk ekstrak. Penurunan tersebut dapat terjadi karena adanya pengaruh dari maltodekstrin pada bubuk ekstrak. Maltodekstrin bersifat higroskopis, sehingga dapat mengikat uap air pada saat pemanggangan cheesecake (teknik au bain marie) yang menyebabkan kekerasan produk menjadi lebih rendah. Hasil ini sesuai dengan penelitian Colla et al. (2018), bahwa penambahan maltodekstrin pada produk kue akan menurunkan tingkat kekerasan kue.

Hasil analisis warna pada produk cheesecake kontrol memiliki nilai L paling tinggi $(81,67)$, sedangkan cheesecake C $(15 \%)$ memiliki nilai $\mathrm{L}$ terendah $(55,78)$. Hal ini menunjukkan bahwa adanya penambahan bubuk ekstrak kubis merah maka tingkat kecerahan produk akan semakin berkurang. Seiring dengan adanya penambahan bubuk ekstrak pada cheesecake, warna produk menjadi semakin ungu.

Nilai a pada cheesecake C $(15 \%)$ memiliki hasil tertinggi (12,76), sedangkan cheesecake kontrol memiliki hasil terendah $(5,19)$. Hasil ini menunjukkan bahwa semakin tinggi konsentrasi bubuk ekstrak yang ditambahkan, maka nilai a akan semakin tinggi dan produk akan semakin mengarah ke warna merah. Hal ini sesuai dengan teori dari deMan (1999) yang menyatakan bahwa nilai a yang semakin tinggi menunjukkan produk semakin berwarna merah.

Tabel 4. Kualitas fisik penambahan bubuk ekstrak kubis merah pada cheesecake

\begin{tabular}{ccccc}
\hline \multirow{2}{*}{$\begin{array}{c}\text { Bubuk Ekstrak } \\
\mathbf{( \% )}\end{array}$} & $\begin{array}{c}\text { Kekerasan } \\
\mathbf{( g )}\end{array}$ & $\mathbf{L}$ & $\mathbf{a}$ & $\mathbf{b}$ \\
\cline { 3 - 5 } & $224,33 \mathrm{~d}$ & $81,67 \mathrm{~d}$ & $5,19 \mathrm{a}$ & $26,35 \mathrm{~d}$ \\
\hline $0(\mathrm{~K})$ & $162,00 \mathrm{c}$ & $68,23 \mathrm{c}$ & $5,70 \mathrm{a}$ & $11,14 \mathrm{c}$ \\
$5(\mathrm{~A})$ & $142,17 \mathrm{~b}$ & $61,53 \mathrm{~b}$ & $9,90 \mathrm{~b}$ & $8,17 \mathrm{~b}$ \\
$10(\mathrm{~B})$ & $94,83 \mathrm{a}$ & $55,78 \mathrm{a}$ & $12,76 \mathrm{c}$ & $4,91 \mathrm{a}$ \\
$15(\mathrm{C})$ & & &
\end{tabular}

*Nilai yang diikuti huruf yang sama pada kolom menunjukkan tidak adanya beda nyata $(a=0,05$ tingkat kepercayaan 95\%) 
Jurnal Teknologi Pertanian Vol. 22 No. 3 [Desember 2021] 221-236

Penambahan Bubuk Ekstrak Kubis Merah Sebagai Sumber Antioksidan dan Pewarna Alami Pada Cheesecake

[Wuwur dkk]

Hasil analisis warna yang didapat sudah sesuai dengan kenampakan visual produk. Cheesecake kontrol memiliki warna putih agak kekuningan dan seiring dengan adanya penambahan bubuk ekstrak kubis merah, cheesecake akan semakin berwarna ungu tua. Campuran warna merah dan biru akan membentuk warna ungu. Warna ungu pada produk cheesecake dipengaruhi oleh adanya antosianin yang merupakan pigmen warna pada kubis merah dan dapat berperan sebagai pewarna alami (He et al., 2015).

\section{Kualitas Mikrobiologi Penambahan Bubuk Ekstrak Kubis Merah pada Cheesecake}

Kualitas mikrobiologi produk diuji dengan menghitung angka lempeng total (ALT) dan keberadaan Salmonella sp. Hasil uji kualitas mikrobiologi dapat dilihat pada Tabel 5. ALT cheesecake kontrol dan cheesecake dengan variasi penambahan bubuk ekstrak kubis merah berada pada kisaran 2,71-4,48 log $\mathrm{CFU} / \mathrm{g}$. ALT produk cheesecake telah sesuai dengan standar yang ditetapkan oleh BOPM (2016), yaitu sebesar $6 \log$ CFU/g.

Angka lempeng total yang cenderung mengalami peningkatan seiring dengan penambahan bubuk ekstrak kubis merah dapat disebabkan oleh tersedianya nutrisi pada produk yang mendukung pertumbuhan mikrobia seperti sumber energi, mineral, nitrogen, dan vitamin. Mikrobia dapat memperoleh energi dari hasil metabolisme karbohidrat dan asam amino. Beberapa mikrobia juga memerlukan mineral seperti besi, fosfor, kalsium, magnesium, dan kalium untuk menunjang pertumbuhannya (Arisman, 2009). Hal ini sesuai dengan hasil uji kadar abu, kadar protein, dan kadar karbohidrat yang meningkat seiring dengan adanya penambahan konsentrasi bubuk ekstrak kubis merah, sehingga memungkinkan mikrobia tumbuh dengan memanfaatkan nutrisi tersebut. Hasil uji Salmonella sp. pada produk cheesecake kontrol dan dengan penambahan bubuk ekstrak kubis merah adalah negatif. Hasil ini ditandai dengan tidak adanya koloni bakteri dengan inti hitam (Gambar 2). Hal ini menunjukkan bahwa semua produk aman untuk dikonsumsi. Hasil uji Salmonella sp. pada cheesecake sesuai dengan standar mutu yang ditetapkan oleh BPOM (2016), yaitu Salmonella negatif/25 g sampel.

Tabel 5. Kualitas mikrobiologi penambahan bubuk ekstrak kubis merah pada cheesecake

\begin{tabular}{ccc}
\hline Bubuk Ekstrak (\%) & Angka Lempeng Total $(\log$ CFU/g) & Keberadaan Salmonella sp. \\
\hline $0(\mathrm{~K})$ & $2,71 \mathrm{a}$ & Negatif \\
$5(\mathrm{~A})$ & $2,85 \mathrm{a}$ & Negatif \\
$10(\mathrm{~B})$ & $4,48 \mathrm{~b}$ & Negatif \\
$15(\mathrm{C})$ & $4,17 \mathrm{~b}$ & Negatif \\
\hline
\end{tabular}

${ }^{*}$ Nilai yang diikuti huruf yang sama pada kolom menunjukkan tidak adanya beda nyata ( $\mathrm{a}=0,05$ tingkat kepercayaan 95\%)

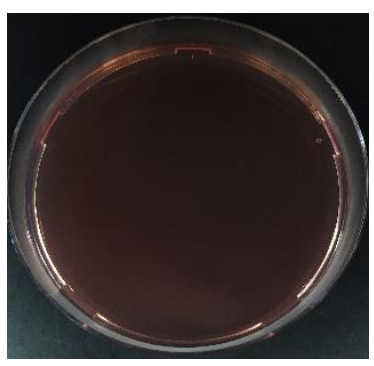

K

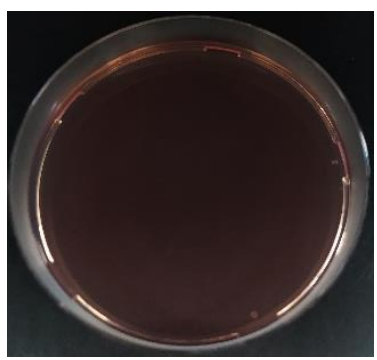

A

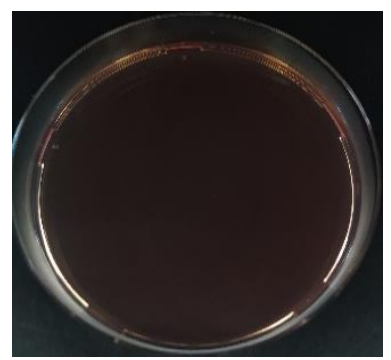

B

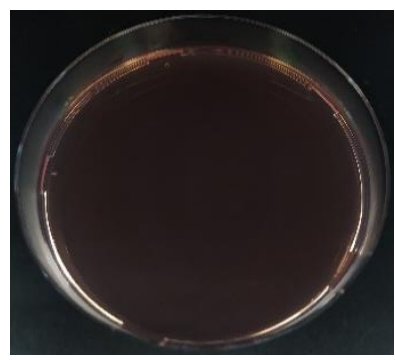

C

Gambar 2. Hasil uji keberadaan Salmonella sp. pada produk cheesecake dengan penambahan bubuk ekstrak kubis merah sebanyak $0 \%(\mathrm{~K}), 5 \%(\mathrm{~A}), 10 \%$ (B) dan $15 \%$ (C) 
Hasil negatif pada uji ini menandakan bahwa kehadiran Salmonella pada produk cheesecake dapat dihambat atau tidak ada. Cheesecake dibuat dengan cara dipanggang pada suhu $150-180^{\circ} \mathrm{C}$, kemudian disimpan di dalam chiller pada suhu $4{ }^{\circ} \mathrm{C}$ sampai produk dikonsumsi. Hal ini menyebabkan Salmonella tidak dapat hidup. Suhu minimum dan maksimum untuk Salmonella sp. masing-masing adalah $5,2{ }^{\circ} \mathrm{C}$ dan $46,2{ }^{\circ} \mathrm{C}$. Suhu optimum pertumbuhan pada $35-37{ }^{\circ} \mathrm{C}$. Proses pemanasan yang melebihi suhu maksimum akan menyebabkan rusaknya membran sel sehingga bakteri mati (Bell dan Kyriakides, 2009).

\section{Kualitas Organoleptik Penambahan Bubuk Ekstrak Kubis Merah Pada Cheesecake}

Uji organoleptik dilakukan dengan empat parameter, yaitu warna, aroma, rasa, dan tekstur. Hasil uji organoleptik produk dapat dilihat pada Tabel 6. Penilaian warna pada cheesecake dengan variasi bubuk ekstrak kubis merah berkisar antara 1,70-2,93. Penilaian warna semakin meningkat seiring dengan adanya penambahan bubuk ekstrak kubis merah. Hal ini dapat disebabkan oleh variasi penambahan bubuk ekstrak kubis yang memberikan warna berbeda pada produk (Gambar 3). Warna pada cheesecake C (15\%) memiliki tingkat kesukaan tertinggi. Peningkatan konsentrasi bubuk ekstrak kubis merah yang ditambahkan menyebabkan warna produk semakin pekat, sehingga disukai panelis (Lestario, 2017).

Parameter uji selanjutnya adalah flavor, yang merupakan kombinasi dari aroma dan rasa. Penilaian aroma pada produk berkisar antara 1,37-3,60 dan penilaian rasa berkisar antara 1,20-3,50. Aroma dan rasa pada cheesecake A (5\%) paling disukai, sedangkan cheesecake C (15\%) paling tidak disukai panelis. Menurut USDA (2005), cheesecake mempunyai ciri khas aroma dan rasa manis seperti keju. Adanya penambahan bubuk ekstrak kubis merah pada produk akan menutup aroma dan rasa keju pada cheesecake sehingga berdampak pada berkurangnya flavor khas produk. Hal ini disebabkan oleh sifat maltodekstrin yang merupakan pembawa aroma yang baik dan efektif pada flavor, sehingga semakin tinggi variasi penambahan bubuk ekstrak kubis merah pada produk maka aroma dan rasa kubis merah semakin kuat (Kumalaningsih, 2014; Winarno dan Winarno, 2017). Aroma dan rasa kubis merah yang kuat pada produk kurang disukai oleh panelis. Tekstur produk merupakan salah satu kinestika produk yang dinilai pada uji orgenoleptik. Penilaian tingkat kesukaan tekstur pada cheesecake dengan variasi penambahan bubuk ekstrak kubis merah berkisar antara 1,43-3,53.

Tabel 6. Organoleptik penambahan bubuk ekstrak kubis merah pada cheesecake

\begin{tabular}{ccccccc}
\hline Bubuk Ekstrak (\%) & Warna & Aroma & Rasa & Tekstur & Rata-rata & Peringkat \\
\hline $0(\mathrm{~K})$ & 1,70 & 2,80 & 3,17 & 2,70 & 2,59 & 2 \\
$5(\mathrm{~A})$ & 2,50 & $\mathbf{3 , 6 0}$ & $\mathbf{3 , 5 0}$ & $\mathbf{3 , 5 3}$ & $\mathbf{3 , 2 8}$ & 1 \\
$10(\mathrm{~B})$ & 2,87 & 2,23 & 2,13 & 2,27 & 2,38 & 3 \\
$15(\mathrm{C})$ & $\mathbf{2 , 9 3}$ & 1,37 & 1,20 & 1,43 & 1,73 & 4 \\
\hline
\end{tabular}

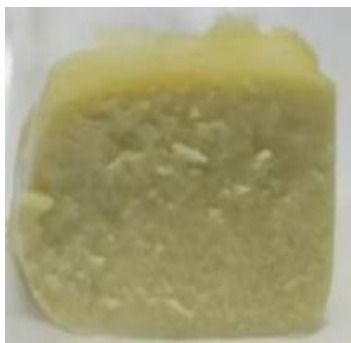

K

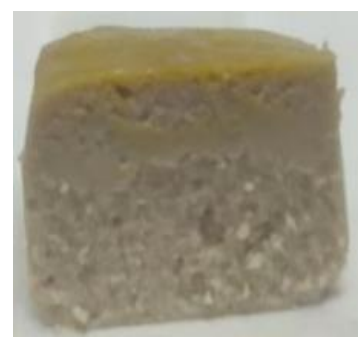

A

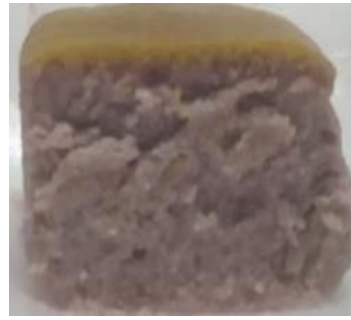

B

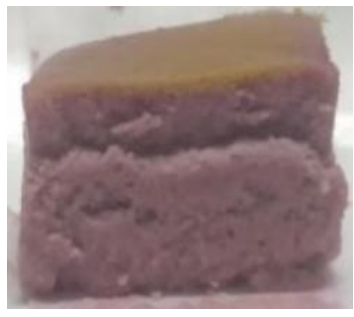

C

Gambar 3. Cheesecake kontrol (K) dan cheesecake dengan penambahan variasi bubuk ekstrak kubis merah $5 \%(A), 10 \%(B), 15 \%(C)$ 
Tekstur cheesecake A paling disukai, sedangkan cheesecake $\mathrm{C}$ paling tidak disukai oleh panelis. Menurut USDA (2005), New York cheesecake memiliki tekstur lembut, tebal, dan padat. Cheesecake C mempunyai kekerasan paling rendah berdasarkan uji tekstur (Tabel 6). Tekstur lunak pada cheesecake kurang disukai oleh panelis. Penambahan bubuk ekstrak kubis merah pada cheesecake menyebabkan produk menjadi lebih lunak dan berdampak pada menurunnya tingkat kesukaan tekstur cheesecake. Hal ini dikarenakan adanya maltodekstrin pada bubuk ekstrak yang dapat menurunkan tekstur kekerasan pada produk (Colla et al., 2018).

Berdasarkan rata-rata nilai warna, aroma, rasa, dan tekstur, diketahui bahwa cheesecake A (5\%) adalah produk yang paling disukai oleh panelis karena memiliki rasa dan aroma khas cheesecake, serta memiliki tekstur yang tidak teralu lunak. Cheesecake kontrol adalah produk yang disukai oleh panelis. Cheesecake B (10\%) adalah produk yang kurang disukai oleh panelis. Produk yang paling tidak disukai oleh panelis adalah Cheesecake C (15\%).

\section{Pengaruh Proses Pada Pembuatan Cheesecake}

Proses pembuatan cheesecake berpengaruh terhadap aktivitas antioksidan, total fenolik, tekstur, dan kualitas mikrobia. Aktivitas antioksidan pada produk cheesecake C (15\%) adalah sebesar $55,58 \%$ dan mempunyai total fenolik sebesar 1,16 mg GAE/100 g DW. Hasil ini lebih tinggi dibandingkan tanpa penambahan bubuk ekstrak.

Beberapa senyawa antosianin pada kubis merah yang stabil pada suhu tinggi yaitu senyawa antosianin yang terasilasi (Ahmadiani et al., 2014; Lukitasari et al., 2017). Senyawa antosianin pada kubis merah dapat stabil pada suhu $80{ }^{\circ} \mathrm{C}$ dan mengalami degradasi sebasar $6 \%$ pada suhu $100{ }^{\circ} \mathrm{C}$ selama 60 menit. Degradasi antosianin akan meningkat seiring dengan terjadinya peningkatan suhu selama pemanasan, namun senyawa antosianin yang mengalami asilasi dengan asam ferulat, asam sinapat, dan asam p-kumarat akan lebih stabil pada suhu tinggi karena titik leleh asam ferulat berada pada suhu $168-171{ }^{\circ} \mathrm{C}$, asam sinapat pada suhu $192{ }^{\circ} \mathrm{C}$, dan asam p-kumarat berada pada suhu $211,5^{\circ} \mathrm{C}$ (Rizk et al., 2009).
Selain senyawa antioksidan, tingkat kekerasan produk cheesecake mengalami penurunan seiring dengan penambahan bubuk ekstrak kubis merah. Hal ini dipengaruhi oleh proses pemanggangan cheesecake yang menggunakan teknik au bain marie (hot-water bath), yaitu proses pemanggangan dengan menggunakan wadah yang berisi air panas. Uap air yang muncul selama proses pemanggangan diikat oleh maltodektrin dari ekstrak bubuk kubis merah, yang bersifat higroskopis, sehingga menyebabkan tekstur menjadi lunak. Hasil ini sesuai dengan penelitian Colla et al. (2018), di mana penambahan maltodekstrin pada produk kue akan menurunkan tekstur kue.

Proses pemanggangan pada suhu tinggi, yaitu $180{ }^{\circ} \mathrm{C}$, menyebabkan kualitas mikrobia pada produk cheesecake sesuai dengan standar ALT yang telah ditetapkan BPOM (2016) sebesar $6 \log \mathrm{CFU} / \mathrm{g}$ dan standar Salmonella negatif/25 g sampel. Suhu minimum dan maksimum untuk Salmonella sp. masingmasing adalah $5,2{ }^{\circ} \mathrm{C}$ dan $46,2{ }^{\circ} \mathrm{C}$, serta suhu optimum pertumbuhan pada $35-37^{\circ} \mathrm{C}$. Proses pemanasan yang melebihi suhu maksimum menyebabkan rusaknya membran sel, sehingga bakteri mati (Bell dan Kyriakides, 2009).

\section{SIMPULAN}

Penambahan variasi bubuk ekstrak kubis merah pada cheesecake memberikan pengaruh terhadap kualitas cheesecake meliputi kadar abu, kadar air, kadar protein, kadar karbohidrat, kadar lemak, total fenolik, aktivitas antioksidan, tekstur, warna, dan angka lempeng total (ALT), namun tidak memberikan pengaruh pada total asam tertitrasi (TAT) dan keberadaan Salmonella sp. Cheesecake dengan penambahan bubuk ekstrak kubis merah sebanyak 15\% menghasilkan kualitas terbaik berdasarkan parameter kimia dan warna, namun kurang disukai berdasarkan parameter organoleptik. Cheesecake dengan penambahan bubuk ekstrak kubis merah sebanyak 5\% menghasilkan kualitas terbaik berdasarkan parameter organoleptik dan mikrobiologi. 


\section{DAFTAR PUSTAKA}

Adelanwa, E, -B., Medugu, J, -M., 2015. Variation in the nutrient composition of red and green cabbage (Brassica oleracea) with respect to age at harvest. Journal of Applied Agricultural Research. 7, 183-189.

Ahmadiani, -N., Robbins, R, -J., Collins, T, -M., Giusti, M, -M., 2014. Anthocyanins contents, profiles, and color characteristics of red cabbage extracts from different cultivars and maturity stages. Journal of Agricultural and Food Chemistry. 62, 7524-7531. https://doi.org/10.1021/jf501991q

AOAC, 2005. Official Methods of Analysis of AOAC International, 18th ed. AOAC International, Gaithersburg

AOAC, 1995. Official methods of analysis, 16th ed. AOAC International, Washington DC

Arisandi, Y. 2001. Studi Tentang Pengaruh Kopigmentasi Terhadap Stabilitas Antosianin dari Kulit Buah Anggur (Alphonso lavalle). Skripsi. Universitas Brawijaya. Malang

Arisman, 2009. Buku Ajar Ilmu Gizi Keracunan Makanan. EGC, Jakarta

Ashfaq, -F., Butt, M, -S., Nazir, -A., Jamil, -A., 2018. Compositional analysis of pakistani green and red cabbage. Pakistan Journal of Agricultural Sciences. 55, 191-196. https://doi.org/10.21162/PAKJAS/18.6547

Badola, -R., Singh, R, R, -B., Panjagari, N, -R., Singh, A, -K., Hussain, S, -A., 2017. Effect of selected humectants as water activity modifiers on the quality of model khoa system. Indian Journal of Dairy Science. 70, 145-154

Barku, V, Y, -A., Opoku-Boahen, -Y., OwusuAnsah, -E., Mensah, E, -F., 2013. Antioxidant activity and the estimation of total phenolic and flavonoid contents of the root extract of Amaranthus spinosus. Asian Journal of Plant Science and Research. 3, 69-74

Bell, C., Kyriakides, A. 2009. 'Salmonella'. Dalam Blackburn, -C. de -W., McClure, P, -J. (Ed.). Foodborne Pathogens: Hazards, Risk Analysis and Control. Woodhead, Cambridge, UK

BPOM, 2016. Peraturan Kepala Badan Pengawas Obat dan Makanan Republik Indonesia Nomor 16 Tahun 2016
Tentang Kriteria Mikrobiologi dalam Pangan Olahan. Badan Pengawas Obat dan Makanan, Indonesia

BPOM, 2013. Peraturan Kepala Badan Pengawas Obat dan Makanan Republik Indonesia Nomor 37 Tahun 2013 Tentang Batas Maksimum Penggunaan Bahan Tambahan Pangan Pewarna. Badan Pengawas Obat dan Makanan, Indonesia

BSN, 2015. Cara Uji Mikrobilogi: Penentuan Angka Lempeng Total (ALT) pada Produk Perikanan. SNI 2332.3:2015

BSN, 2006. Cara Uji Mikrobilogi: Penentuan Salmonella pada Produk Perikanan. SNI 01-2332.2:2006.

Chandra, Z, -A., Swasti, Y, -R., Pranata, F, -S., 2021. Substitusi Tepung sukun sebagai sumber serat untuk peningkatan kualitas flacky crackers. Jurnal Teknologi Pertanian Andalas. 25, 153-162. https://doi.org/10.25077/jtpa.25.2.153161.2021

Colla, -K., Costanzo, -A., Gamlath, S., 2018. Fat replacers in baked food products. Foods. 7, 112. https://doi.org/10.3390/foods7120192

deMan, JM. 1999. Principles of Food Chemistry, Third. ed. Aspen Publishers, Inc., Gaithersburg, Maryland

Dwipayanti, N, K, -Y., Putra, G, P, -G., Suhendra, L., 2020. Karakteristik ekstrak kulit buah kakao (Theobroma cacao L.) sebagai sumber antioksidan pada perlakuan perbandingan bahan dengan pelarut dan waktu maserasi. Jurnal Rekayasa dan Manajemen Agroindustri. 8, 210-222. https://doi.org/10.24843/jrma.2020.v08.i02. p06

Han, -J., Britten, -M., St-Gelais, -D., Champagne, C, -P., Fustier, -P., Salmieri, -S., Lacroix, -M., 2011. Polyphenolic compounds as functional ingredients in cheese. Food Chemistry. 124, 1589-1594. https://doi.org/10.1016/j.foodchem.201 0.08 .021

Hasanah, -M., Maharani, -B., Munarsih, -E., 2017. Daya antioksidan ekstrak dan fraksi daun kopi robusta (Coffea Robusta) terhadap pereaksi dpph (2,2-difenil-1-pikrilhidrazil). Indonesian Journal of Pharmaceutical Science and Technology. 4, 42-49. https://doi.org/10.15416/ijpst.v4i2.10456 
He, X, -L., Li, X, -L., Lv, Y, -P., He, -Q., 2015. Composition and color stability of anthocyanin-based extract from purple sweet potato. Journal of Food Science and Technology. 35, 468-473. https://doi.org/10.1590/1678457 X.6687

Izzo, -L., Rodríguez-Carrasco, -Y., Pacific, -S., Castaldo, -L., Narváez, -A., Ritieni, -A., 2020. Colon bioaccessibility under in vitro gastrointestinal digestion of different coffee brews chemically profiled through UHPLC-Q-orbitrap HRMS. Antioxidants. 9, 1-17. https:/ / doi.org/10.3390/antiox9100955

Jiao, -Y., Jiang, -Y., Zhai, -W., Yang, -Z., 2012. Studies on antioxidant capacity of anthocyanin extract from purple sweet potato (Ipomoea batatas L.). African Journal of Biotechnology. 11, 7046-7054. https://doi.org/10.5897/ajb11.3859

Kalukiningrum, S. 2012. Pengembangan Produk Cake dengan Substitusi Tepung Mocaf. Proyek Akhir. Universitas Negeri Yogyakarta. Sleman

Karoui, I, -J., Jalloul, A, -B, Jihene, -A., Abderrabba, -M., 2018. Characterization of bioactive compounds, Antioxidant Properties and Antimicrobial Activity of Red And White Cabbage Leaves Extracts. Journal of Chemistry: Education Research and Practice. 2, 1-8. https://doi.org/10.33140/jcerp/02/01/ 05

Khaira, -K., 2010. Menangkal radikal bebas dengan anti-oksidan. Sainstek : Jurnal Sains dan Teknologi. 2, 183-187. https://doi.org/10.31958/js.v2i2.28

Khan, I, -T., Nadeem, -M., Imran, -M., Ullah, R., Ajmal, -M., Jaspal, M, -H., 2019. Antioxidant properties of Milk and dairy products: a comprehensive review of the current knowledge. Lipids in Health and Disease. 18, 1-13. https:/ / doi.org/10.1186/s12944-0190969-8

Kumalaningsih, S. 2014. Pohon Industri Potensial pada Sistem Agroindustri. UB Press, Malang

Lestario, LN. 2017. Antosianin: Sifat Kimia, Perannya dalam Kesehatan, dan Prospeknya sebagai Pewarna Makanan. UGM Press, Sleman

Lucera, -A., Costa, -C., Marinelli, -V.,
Saccotelli, M, -A., Del Nobile, M, -A., Conte, -A., 2018. Fruit and vegetable byproducts to fortify spreadable cheese. Antioxidants. 7, 1-10. https://doi.org/10.3390/antiox7050061

Lukitasari, D, -M., Indrawati, -R., Chandra, R, D., Heriyanto, -H., Limantara, -L., 2017. Mikroenkapsulasi pigmen dari kubis merah: studi intensitas warna dan aktivitas antioksidan. Jurnal Teknologi dan Industri Pangan. 28, 1-9. https:/ / doi.org/10.6066/jtip.2017.28.1.1

Martin-Diana, A, -B., Izquierdo, -N., Albertos, I., Sanchez, M, -S., Herrero, -A., Sanz, M, -A., Rico, D., 2017. Valorization of carob's germ and seed peel as natural antioxidant ingredients in gluten-free crackers. Journal of Food Processing and Preservation. 41, e12770. https://doi.org/10.1111/jfpp.12770

Maulana, A. 2016. Analisis Parameter Mutu dan Kadar Flavonoid pada Produk Teh Hitam Celup. Skripsi. Universitas Pasundan. Bandung

Mazza, G, Miniati, E. (Ed.), 2018. Anthocyanins in Fruits, Vegetables, and Grains, 1st ed. CRC Press, Boca Raton. https://doi.org/10.1201/9781351069700

Molyneux, -P., 2004. The use of the stable free radical diphenylpicryl-hydrazyl (DPPH) for estimating antioxidant activity. Songklanakarin Journal of Science and Technology. 26, 211-219.

Nugroho, -P., Dwiloka, -B., Rizqiati, -H., 2018. Rendemen, nilai $\mathrm{pH}$, tekstur, dan aktivitas antioksidan keju segar dengan bahan pengasam ekstrak bunga rosella ungu (Hibiscus sabdariffa L.). Jurnal Teknologi Pangan. 2, 33-39. https://doi.org/10.14710/jtp.2.1.\%25p

Nurul, S, -R., Asmah, -R., 2014. Variability in nutritional composition and phytochemical properties of red pitaya (Hylocereus polyrhizus) from Malaysia and Australia. International Food Research Journal. 21, 1689-1697

Ondagau, D, -C., Ridhay, -A., Nurakhirawati, N., 2019. Karakterisasi pigmen hasil ekstraksi air-etanol dari buah senggani (Melastoma malabathricum). KOVALEN: Jurnal Riset Kimia. 4, 228-236. https:/ / doi.org/10.22487/kovalen.2018. v4.i3.11848 
Park, -S., Arasu, M, -V., Lee, M, -K., Chun, J, H., Seo, J, -M., Lee, S, -W., Al-Dhabi, N, A., Kim, S, -J., 2014. Quantification of glucosinolates, anthocyanins, free amino acids, and vitamin $C$ in inbred lines of cabbage (Brassica oleracea L.). Food Chemistry. $\quad 145$, 77-85. https://doi.org/10.1016/j.foodchem.201 3.08.010

Pehlivan, FE. 2017. Vitamin C: An Antioxidant Agent'. Dalam Hamza, -A. (Ed.), Vitamin C. IntechOpen. https://doi.org/10.5772/intechopen.69660

Pereira, D, -M., Valentão, -P., Pereira, J, -A., Andrade, P, -B., 2009. Phenolics: From chemistry to biology. Molecules. 14, 2202-2211. https://doi.org/10.3390/molecules14062202

Permatasari, N, -A., Afifah, -F., 2020. Pembuatan dan pengujian stabilitas bubuk pewarna alami dari daun bayam merah (Alternanthera amoena Voss.). Jurnal Rekayasa dan Manajemen Agroindustri. $\quad 8, \quad 409-422$. https://doi.org/10.24843/jrma.2020.v08 .i03.p10

Podsędek, -A., Sosnowska, -D., Redzynia, -M., Anders, -B., 2006. Antioxidant capacity and content of Brassica oleracea dietary antioxidants. International Journal of Food Science \& Technology. 41, 49-58. https://doi.org/10.1111/j.13652621.2006.01260.x

Prasetya, I, W, G, -A., Putra, G, P, -G., Wrasiati, L, -P., 2020. Pengaruh jenis pelarut dan waktu maserasi terhadap ekstrak kulit biji kakao (Theobroma cacao L.) sebagai sumber antioksidan. Jurnal Rekayasa dan Manajemen Agroindustri. 8, 150-159. https://doi.org/10.24843/JRMA.2020.v 08.i01.p15

Rahardjo, P, A, -C., 2018. Karakteristik Fisikokkima Serbuk Pewarna Alami dari Kubis Merah (Brassica oleracea L.) Hasil Cabinet Drying dan Freeze Drying dengan Variasi Maltodekstrin dan Isolat Protein Kedelai. Skripsi. Universitas Katolik Soegijapranata. Semarang

Rauf, -R., Santoso, -U., Suparmo, 2010. Aktivitas penangkapan radikal DPPH ekstrak gambir (Uncaria gambir Roxb.). Agritech. 30, 1-5. https://doi.org/10.22146/agritech.9684

Rizk, E, -M., Azouz, -A., Hareedy, L, A, -M., 2009. Evaluation of red cabbage anthocyanin pigments and its potential uses as antioxidant and natural food colorants. Arab Universities Journal of Agricultural Sciences. 17, 361-372. https://doi.org/10.21608/AJS.2009.1494 6

Santoso, W, E, -A., Estiasih, -T., 2014. Kopigmentasi Ubi Jalar Ungu (Ipomoea Batatas var. Ayamurasaki) dengan Kopigmen Na-Kasenat dan Protein Whey Serta Stabilitasnya Terhadap Pemanasan. Jurnal Pangan dan Agroindustri. 2, 121-127.

Saputri, N, -E., Hidayah, -N., Muttalib, Y, -S., 2021. Komposisi nilai gizi pempek ikan tenggiri (Scomberomorus Commersonii) dengan penambahan wortel (Daucus Carota). Poltekita : Jurnal Ilmu Kesehatan. 15 ,

143-149. https://doi.org/10.33860/jik.v15i2.488

Sembiring, NVN. 2009. Pengaruh Kadar Air dari Bubuk Teh Hasil Fermentasi Terhadap Kapasitas Produksi pada Stasiun Pengeringan di Pabrik Teh PTPN IV Unit Kebun Bah Butong. Karya Ilmiah. Universitas Sumatera Utara. Medan

Shepard, -L., Miracle, R, -E., Leksrisompong, -P., Drake, M, -A., 2013. Relating sensory and chemical properties of sour cream to consumer acceptance. Journal of Dairy Science. 96, 54355454. https://doi.org/10.3168/jds.2012-6317

Suryani, -R., Nisa, F, -C., 2015. Modifikasi pati singkong (Manihot esculenta) dengan enzim a-amilase sebagai agen pembuih serta aplikasinya pada proses pembuatan marshmallow. Jurnal Pangan dan Agroindustri. 3, 723-733.

Takahata, -Y., Kai, -Y., Tanaka, -M., Nakayama, -H., Yoshinaga, -M., 2011. Enlargement of the variances in amount and composition of anthocyanin pigments in sweetpotato storage roots and their effect on the differences in DPPH radical-scavenging activity. Scientia Horticulturae. 127, 469-474. https://doi.org/10.1016/j.scienta.2010.1 0.010

Tze, N, -L., Han, C, -P., Yusof, Y, -A., Ling, C, N., Talib, R, -A., Taip, F, -S., Aziz, M, G., 2012. Physicochemical and nutritional properties of spray-dried pitaya fruit powder as natural colorant. Food Science and Biotechnology. 21, 675682. https://doi.org/10.1007/s10068012-0088-z 
Jurnal Teknologi Pertanian Vol. 22 No. 3 [Desember 2021] 221-236

Penambahan Bubuk Ekstrak Kubis Merah Sebagai Sumber Antioksidan dan Pewarna Alami Pada Cheesecake

[Wuwur dkk]

USDA, 2005. A-A-20093A: Commercial Item Description Cheesecake, Frozen and Mix, No Bake.

Winarno, F, Winarno, SAA. 2017. Gastronomi Molekuler. Gramedia Pustaka Utama, Jakarta.

Yasin, N, M, -N., Shalaby, S, -M., 2013. Physiochemical and sensory properties of functional low fat cheesecake manufactured using cottage cheese. Annals of Agricultural Sciences. 58, 61-67. https://doi.org/10.1016/j.aoas.2013.01. 009
Załuski, -D., Ciesla, -Ł., Janeczko, -Z., 2015. 'The structure-activity relationships of plant secondary metabolites with antimicrobial, free radical scavenging and inhibitory activity toward selected enzymes'. Dalam Atta-ur-Rahman (Ed.). Studies in Natural Products Chemistry. Elsevier B.V., Amsterdam, Netherlands, hal. 217-249. https://doi.org/10.1016/B978-0444-63473-3.00007-1

Zein, -U., Newi, E, -E, 2019. Buku Ajar Ilmu Kesehatan (Memahami Gejala, Tanda Dan Mitos). Deepublish, Sleman 